\title{
COMPARISON OF MORPHOLOGICAL CHARACTERISTICS OF PITU- ITARY GLAND BETWEEN THE DIFFERENT AGE GROUPS
}

\section{Geetha Jayachandran.}

Assistant Professor, Department of Anatomy, Government Medical College, Manjeri, Malappuram (Dist), Kerala, India.

\section{ABSTRACT}

Background: The pituitary gland (PTG) size, shape will change according to the age in response to the changes in the hormonal environment. Hence care should be taken while evaluating the PTG disorders. This present study conducted to evaluate the morphological changes in PTG with relation to age.

Materials and Methods: This study was conducted in the Department of Anatomy was approved by Institutional Human Ethics Committee. A total of 73 PTG specimens were included in this study. They are divided in to six groups based on the age. G-I (Foetus), G-II (1-10 Y), G-III (11-30 Y), G-IV (31-50 Y), G-V (51-70 Y) and G-VI(Above 71 $Y)$. All the specimens were subjected for $\mathrm{H} \& \mathrm{E}$ stain. The slides were observed for morphological changes. The data was expressed in MEAN $\pm S D$ and Statistical Package for Social Sciences (SPSS 16.0) version used for analysis.

Results: More number of males was in group-V and females in group-IV. Pars intermedia had maximum thickness in foetal life. Basophilic zone was not seen in foetal life but it is more prominent in other age groups. Cellularity increased as age progress. Pars anterior and nervosa showed more vascularity compared to interior. As age progress this vascularity is decreased.

Conclusion: From the study observations it can be concluded that as age progress there is a significant changes in the PTG morphology. Knowledge about these changes can useful for the diagnosis and treatment of various disorders of PTG.

KEY WORDS: Morphology, Endocrine disorders, pituitary gland, Haematoxylin \& Eosin.

Address for Correspondence: Dr Geetha Jayachandran, Assistant Professor, Department of Anatomy, Government Medical College, Manjeri-676121, Malappuram (Dist), Kerala, India.

Mobile No:+91-7989240468 E-Mail: sarathgrey@gmail.com

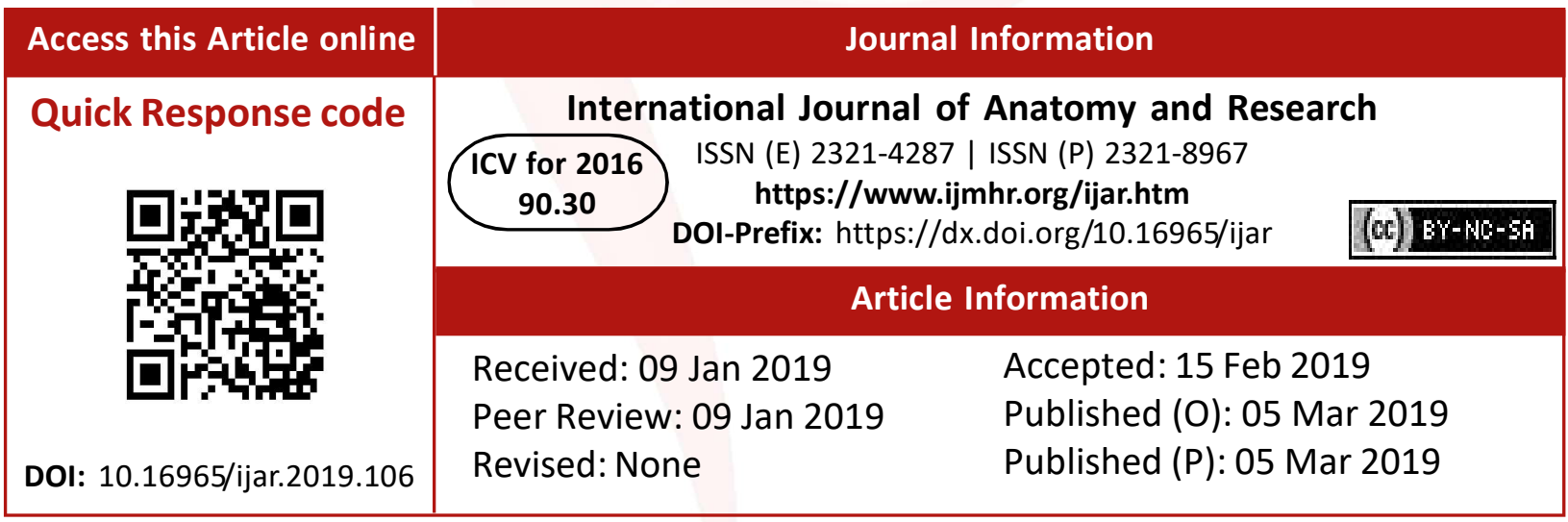

\section{INTRODUCTION}

PTG has a important role to maintain normal physiological functions in the body. It has a role in the reproduction, stress adaptive changes, electrolyte and water balance, contraction of uterus, milk production, thyroid hormone synthesis, growth and development, puberty and skin pigmentation [1-4]. All the PTG hormones have role in the ageing process. As age progress there will be significant changes in all parts of
PTG $[5,6]$. These changes can alter the physiological functions of the body. Ageing is marked by changes in physical and psychological status of the human. There will be changes in physical appears (Increase or decrease in the body size) and psychological (Thought process, anxiety, depression). PTG secrete various hormones from different parts. These are synthesized and secreted by special cells in the glands [7]. Any alterations in these cells lead to hypo or hyper 
secretion of hormones. The aim of the study to evaluate and compare the changes in PTG between different age group peoples.

\section{MATERIALS AND METHODS}

This study was done in the Department of Anatomy. The study protocol was approved by Institutional Human Ethics Committee.

\section{Inclusion criteria}

- Post mortem done within 6 hours of death.

- Cases in which cause of death was not head injury.

- Apparently healthy fetuses.

\section{Exclusion Criteria}

- Post mortem done after 6 hours of death.

- Cases in which cause of death was not known or was due to severe head injury.

- Fetuses with congenital neurological anomalies.

Study groups:A total of 73 PTG specimens were collected based on the inclusion and exclusion criteria. There specimens were divided into 6 groups based on the age. Group-I (Less than 1 year), Group-II (1-10 Y), Group-III (11-30 Y), Group-IV (31-50 Y), Group-V (51-70 Y) and Group-VI (above $71 \mathrm{Y}$ ).

Collection of specimens: After removal of brain, the gland was scooped out from sella turcica after breaking posterior clenoid process. All specimens after removal were immediately transferred to the fixative solution $(10 \%$ formalin\&Bouin's fluid).

Preparation of H\&E slides: All the specimens were fixed in Bouin's fluid for two days. $10 \%$ formalin was also tried as fixative. The whole gland was used as one block without sectioning. After the specimen was fixed, it was dehydrated by placing successively in gradually increasing strength of alcohol solution. The dehydrated specimen were cleared in xylene(), impregnated with molten paraffin and then embedded in paraffin wax. Sections were taken from the block at a thickness of 5 microns. Only transverse sections of the gland were taken.The sections after incubation were stained with haematoxylin and eosin. Ehrlich's haematoxylin was used since it could be kept for years after ripening and give a brilliant nuclear stain. The slides were studied under microscope [8].

Statistical analysis: The data was expressed in number, mean and standard deviation. Statistical Package for Social Sciences (SPSS 16.0) version used for analysis. Chi square test applied to find the statistical significant between the groups. $P$ value less than $0.05 \quad(p<0.05)$ considered statistically significant at $95 \%$ confidence interval.

\section{RESULTS}

A total of 73 PTG specimens were divided into six groups and observed for morphological changes. Maximum number of specimens was present in Group-IV (Graph-1). Males were more compared to females in Group-III, IV, V and VI. Females were more in rest of the groups (Graph-2). In the Paras anterior G-I showed high cellularity, G-IIl showed high acidophils, GroupIII, IV, V showed high basophils and G-VI showed high chromophobes in periphery. This was statistically significant compared to other groups (Table-1). In the interior of pars anterior high cellulariry (G-III), acidophils (G-VI), Basophils (G-V) and chromopobes (G-II) these showed significant difference compared to other groups (Table-2). In the paras intermedia significant number of cellurarity (G-I), acidophils (G-V), basophils (G-III) and chromophobes (G-II) was seen compared to other groups (Table-3). G-I showed significant difference in periphery and interior compared to other groups in pars nervosa (Table-4).

Graph 1: Distribution of specimens in each group.

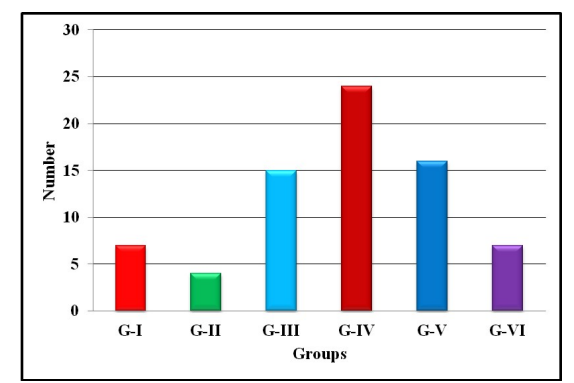

Graph 2: Distribution of specimens based on gender.

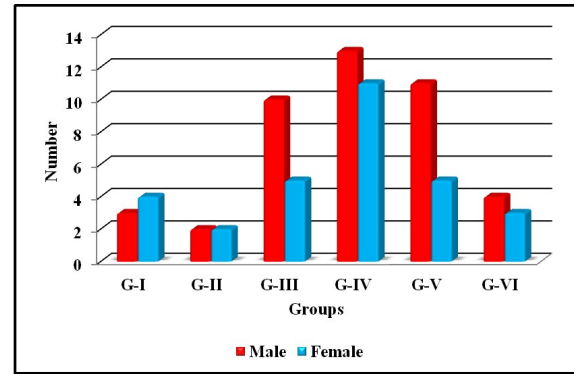


Table 1: Comparison of mean values of Paras anterior of periphery between the groups.

\begin{tabular}{|c|c|c|c|c|}
\hline \multirow{2}{*}{ Groups } & \multicolumn{4}{|c|}{ Periphery (MEAN \pm SD) } \\
\cline { 2 - 5 } & Cellularity & Acidophils & Basophils & Chromophobes \\
\hline $\begin{array}{c}\text { Group-I } \\
\text { (Foeuts) }\end{array}$ & $59.00 \pm 7.43$ & $26.42 \pm 2.63$ & $2.28 \pm 0.75^{*}$ & $71.57 \pm 2.63$ \\
\hline $\begin{array}{c}\text { Group-II } \\
(1-10 \text { Y) }\end{array}$ & $48.75 \pm 6.13$ & $27.00 \pm 0.81$ & $1.50 \pm 0.57^{*}$ & $71.50 \pm 1.29$ \\
\hline $\begin{array}{c}\text { Group-III } \\
(11-30 \text { Y) }\end{array}$ & $57.86 \pm 8.51$ & $37.86 \pm 1.64$ & $25.60 \pm 1.18$ & $36.26 \pm 1.57^{*}$ \\
\hline $\begin{array}{c}\text { Group-IV } \\
(31-50 \text { Y) }\end{array}$ & $29.33 \pm 3.29 *$ & $35.75 \pm 3.45$ & $25.66 \pm 1.49$ & $38.41 \pm 3.42^{*}$ \\
\hline $\begin{array}{c}\text { Group-V } \\
\text { (51-70 Y) }\end{array}$ & $19.93 \pm 3.53^{*}$ & $23.43 \pm 1.31$ & $25.31 \pm 1.70$ & $51.31 \pm 2.21$ \\
\hline $\begin{array}{c}\text { Group-VI } \\
\text { (above 71 Y) }\end{array}$ & $15.00 \pm 2.58^{*}$ & $8.00 \pm 7.30 *$ & $10.57 \pm 6.16^{*}$ & $81.57 \pm 12.35$ \\
\hline
\end{tabular}

$\left({ }^{*} \mathrm{p}<0.05\right.$ significant compared to other groups)

Table 2: Comparison of mean values of paras anterior of interior between the groups.

\begin{tabular}{|c|c|c|c|c|}
\hline \multirow{2}{*}{ Groups } & \multicolumn{4}{|c|}{ Interior (MEAN \pm SD) } \\
\cline { 2 - 5 } & Cellularity & Acidophils & Basophils & Chromophobes \\
\hline $\begin{array}{c}\text { Group-I } \\
\text { (Foeuts) }\end{array}$ & $64.00 \pm 7.65$ & $21.57 \pm 6.26^{*}$ & $3.14 \pm 1.06^{*}$ & $72.57 \pm 7.34$ \\
\hline $\begin{array}{c}\text { Group-II } \\
\text { (1-10 Y) }\end{array}$ & $65.75 \pm 2.21$ & $17.75 \pm 0.95^{*}$ & $3.00 \pm 0.00^{*}$ & $79.25 \pm 0.95$ \\
\hline $\begin{array}{c}\text { Group-III } \\
(11-30 \text { Y) }\end{array}$ & $70.46 \pm 6.16$ & $42.46 \pm 2.92$ & $21.26 \pm 1.27$ & $36.26 \pm 3.0 * 5$ \\
\hline $\begin{array}{c}\text { Group-IV } \\
\text { (31-50 Y) }\end{array}$ & $35.29 \pm 3.89 *$ & $33.62 \pm 7.27$ & $22.37 \pm 1.76$ & $44.00 \pm 6.83^{*}$ \\
\hline $\begin{array}{c}\text { Group-V } \\
\text { (51-70 Y) }\end{array}$ & $26.62 \pm 3.51^{*}$ & $25.12 \pm 1.20^{*}$ & $24.37 \pm 5.34$ & $52.50 \pm 2.50$ \\
\hline $\begin{array}{c}\text { Group-VI } \\
\text { (above 71 Y) }\end{array}$ & $22.00 \pm 2.38^{*}$ & $43.57 \pm 11.17$ & $16.71 \pm 17.21 *$ & $39.71 \pm 25.92^{*}$ \\
\hline
\end{tabular}

( ${ }^{*} p<0.05$ significant compared to other groups)

Table 3: Comparison of mean values of Paras intermedia between the groups.

\begin{tabular}{|c|c|c|c|c|}
\hline \multirow{2}{*}{ Groups } & \multicolumn{4}{|c|}{ Paras intermedia (MEAN \pm SD) } \\
\cline { 2 - 5 } & Cellularity & Acidophils & Basophils & Chromophobes \\
\hline $\begin{array}{c}\text { Group-I } \\
\text { (Foeuts) }\end{array}$ & $138.28 \pm 31.11$ & $19.14 \pm 2.85$ & $2.42 \pm 1.51^{*}$ & $77.42 \pm 3.25$ \\
\hline $\begin{array}{c}\text { Group-II } \\
(1-10 \text { Y) }\end{array}$ & $94.75 \pm 2.21^{*}$ & $12.50 \pm 0.57^{*}$ & $19.00 \pm 0.81^{*}$ & $68.50 \pm 1.00$ \\
\hline $\begin{array}{c}\text { Group-III } \\
(11-30 \text { Y) }\end{array}$ & $77.00 \pm 12.51^{*}$ & $7.60 \pm 0.73^{*}$ & $39.73 \pm 4.31$ & $51.13 \pm 6.24^{*}$ \\
\hline $\begin{array}{c}\text { Group-IV } \\
(31-50 \text { Y) }\end{array}$ & $54.83 \pm 6.37^{*}$ & $22.91 \pm 1.52$ & $25.83 \pm 0.91$ & $51.25 \pm 1.67^{*}$ \\
\hline $\begin{array}{c}\text { Group-V } \\
(51-70 \text { Y) }\end{array}$ & $40.00 \pm 17.43^{*}$ & $23.56 \pm 1.71$ & $28.87 \pm 3.79$ & $48.00 \pm 2.87^{*}$ \\
\hline $\begin{array}{c}\text { Group-VI } \\
\text { (above 71 Y) }\end{array}$ & $23.71 \pm 6.31^{*}$ & $22.85 \pm 4.48$ & $29.42 \pm 2.22$ & $47.85 \pm 2.85^{*}$ \\
\hline
\end{tabular}

( ${ }^{*} p<0.05$ significant compared to other groups)

Table 4: Comparison of mean values of Paras nervosa.

\begin{tabular}{|c|c|c|}
\hline \multirow{2}{*}{ Groups } & \multicolumn{2}{|c|}{ Paras nervosa (MEAN \pm SD) } \\
\cline { 2 - 3 } & Periphery & Interior \\
\hline Group-I (Foeuts ) & $35.85 \pm 9.59$ & $46.57 \pm 7.93$ \\
\hline Group-II (1-10 Y) & $17.25 \pm 1.70^{*}$ & $20.75 \pm 1.89^{*}$ \\
\hline Group-III (11-30 Y) & $16.40 \pm 3.37^{*}$ & $21.73 \pm 2.76^{*}$ \\
\hline Group-IV (31-50 Y) & $13.08 \pm 2.97^{*}$ & $25.66 \pm 4.17^{*}$ \\
\hline Group-V (51-70 Y) & $12.62 \pm 2.30^{*}$ & $25.62 \pm 4.86^{*}$ \\
\hline Group-VI (above 71 Y) & $13.14 \pm 1.95^{*}$ & $19.71 \pm 1.49^{*}$ \\
\hline
\end{tabular}

( ${ }^{*} p<0.05$ significant compared to other groups)

\section{DISCUSSION}

In this study a total of 73 Pituitary gland specimens obtained, from dead foetuses and autopsies, were studied under light microscopy. The specimens were categorized into six groups based on their age. It was observed that increase in PTG weight as age progress, it was significantly observed in the age between $11-30$ years group compared to other groups. A similar observations was made by Tsunoda T et.al study [9]. Hrvoje IP et.al study observed that as age progress the volume of PTG gland increases. This may be due to increase the number of cells or increase in the size of the cells. These can alters the vascularity and presence of acidphils, basophils and other structure of gland. Thisstudy also proved that as age increased the content of the acidphils, basophils, cellularity and chromophobes changes in all the parts of PTG. These significant changes were more in the middle age compared to children's and old age [10].Pars intermedia is poorly developed in the human and it is mainly composed of cystic spaces lined by hormone cell types. These parts contain less number of chromophobes, acidophils, basophils compared to other parts of the gland. In this study also showed similar observations as like Sylvia LA study [11].

This study showed that there are significant changes in cellularity, acidophils, basophils and chomophobes content in PTG depending on the area of the gland. Peripheral part of PTG showed more changes than inner side of the PTG.

Limitations of the study: Small sample size in some groups, not used any special stains.

\section{CONCLUSION}

It was observed that as age progress there was a significant change in all parts of the PTG. In depth knowledge about these changes give new approaches in the diagnosis and treatment of the various disorders associated with the PTG.

\section{Conflicts of Interests: None}

\section{REFERENCES}

[1]. Johannes DV. Changes in pituitary function with aging and implications for patient care. Nat Rev Endocrinol 2013;9(4):205-5. 
[2]. Hartl F, Fischer C. Morphological changes of the human adenohypophysis and their relations to age, sex and constitution. Z Alternsforsch 1955;8(4):3018.

[3]. Inger K. Sella turcica morphology and the pituitary gland- a new contribution to craniofacial diagnosis based on histology and neuroradiology. Eur J Orthod 2015;37(1):28-36.

[4]. John G, Donald H, David W, Jaime RD. Morphological changes in the pituitary adrenocortical axis in natives of la Paz. IJB 1991;35(1):1-5..

[5]. Toshiaki S, Kalman TK, Bernd WS. Aging and the human pituitary gland. Mayo Clinic Proceedings 1993;68(10):971-7.

[6]. Heuser IJ, Gotthardt U, Schweiger U, Schmider J, Lammers $\mathrm{CH}$, Dettling M. Age associated changes of pituitary adrenocortical hormones regulation in humans: Importance of gender. Neurobiology of aging 1994;15(2):227-31.
[7]. Paez MP, Kuchenbauer F, Arzt E, Stalla GK. Regulation of pituitary hormones and cell proliferation by components of the extracellular matrix. Braz J Med Biol Res 2005;38(10):1487-94.

[8]. Al Brahim NYY, Asa SL. My approach to pathology of the pituitary gland. J Clin Pathol 2006;59(12):124553.

[9]. Tsunoda A, Okuda O, Sato K. MR height of the pituitary gland as a function of age and sex: especially physiological hypertrophy in adolescence and in climacterium. AJNR 1997;18:551-4.

[10]. Hrvoje IP, Tatjana CP, Vlasta V, Ivan K, Mario S. Age and sex related differences in normal pituitary gland and fossa volumes. Frontiers in Bioscinces 2017;9:204-13.

[11]. Sylvia LA. Pituitary histopathology in man: Normal and abnormal. Endo text 2017:1-5.

How to cite this article:

Geetha Jayachandran. COMPARISON OF MORPHOLOGICAL

CHARACTERISTICS OF PITUITARY GLAND BETWEEN THE

DIFFERENT AGE GROUPS. Int J Anat Res 2019;7(1.3):6307-6310.

DOI: $10.16965 /$ ijar.2019.106 